\title{
Progressive $\beta$ Cell Failure in Type 2 Diabetes Mellitus: Microvascular Pancreatic Isletopathy?*
}

\author{
Udaya M. Kabadi 1,2,3\#, Mary U. Kabadi' ${ }^{1}$, Sommany Weber ${ }^{3}$, Aaron Bubolz ${ }^{3}$, \\ Edward Finnerty ${ }^{3}$ \\ ${ }^{1}$ University of lowa Carver College of Medicine, lowa City, lowa, USA \\ ${ }^{2}$ VA Medical Center, Phoenix, Arizona, USA \\ ${ }^{3}$ Des Moines University, Des Moines, lowa, USA \\ Email: ukabadi@email.com
}

Received 11 November 2014; revised 13 December 2014; accepted 22 December 2014

Academic Editor: Sharma S. Prabhakar, Texas Tech University Health Sciences Center, USA

Copyright (C) 2015 by authors and Scientific Research Publishing Inc.

This work is licensed under the Creative Commons Attribution International License (CC BY). http://creativecommons.org/licenses/by/4.0/

(c) (i) Open Access

\section{Abstract}

Background: UKPDS suggested relentless deterioration of $\beta$ cell function as a part of natural course of type 2 diabetes mellitus. However, the course was apparently not universal since many patients maintained glycemic goal $(\mathrm{HbA1c}<7.0 \%)$ at 9 years while receiving conventional life style programs consisting of diet and exercise or/and oral agents. Moreover, $\beta$ cell failure occurred around the same time as the time of onset of microvascular complications. Finally, the exact mechanism of progressive $\beta$ cell failure remains to be defined. It is plausible that $\beta$ cell failure may be due to fibrosis of pancreatic islets secondary to microangiopathy since no organ or tissue is exempt from this complication. Objective: To assess epidemiologic correlation between presence of $\beta$ cell failure and microvascular complications by determining the prevalence of $\beta$ cell failure in subjects with type 2 diabetes with increasing number of known microvascular complications. Methods: 650 Subjects with ages 40 - 75 years and duration of DM 4 - 23 years were divided into 4 groups according to number of microvascular complications, e.g. retinopathy, nephropathy, and neuropathy. $\beta$ cell failure $(\beta-$ ve $)$ is defined as HbA1c $>7.0 \%$ with any therapy or HbA1c $\leq$ $7.0 \%$ with insulin, either monotherapy or in combination with oral agents. $\beta$ cell function is deemed "preserved" $(\beta+$ ve) with HbA1c $<7.0 \%$ with treatment consisting of life style program or/and oral drugs. Results: Prevalence of $\beta$ cell failure progressively rose with increasing number of microvascular complications from 0 to 2 with no further significant rise with 3 complications whereas subjects with preserved $\beta$ cell function declined with increasing number of microvascular

\footnotetext{
${ }^{*}$ The study was presented in part at International Diabetes Federation Meeting in Dubai, UAE in December 2011.

"Corresponding author.
}

How to cite this paper: Kabadi, U.M., Kabadi, M.U., Weber, S., Bubolz, A. and Finnerty, E. (2015) Progressive 8 Cell Failure in Type 2 Diabetes Mellitus: Microvascular Pancreatic Isletopathy? Journal of Diabetes Mellitus, 5, 21-27. 
complications ( $p<0.01$ for both groups). Significant relationships were also noted between the age and the duration of diabetes and prevalence of $\beta$ cell failure $(p<0.01)$. The relative risks rose progressively for $\beta$ cell failure $/ \beta$ cell preserved with increasing number of microvascular complications as well as the greater duration of Diabetes. However, a significantly $(p<0.01)$ higher relative risk for $\beta$ cell failure persisted for rising number of microvascular complications even after eliminating the influence of age and duration of diabetes. Conclusion: $\beta$ cell failure may be a manifestation of microvascular pancreatic isletopathy similar to other microvascular complications.

\section{Keywords}

Type 2 Diabetes, Beta Cell Failure, Pancreatic Isletopathy

\section{Introduction}

UKPDS suggested relentless deterioration of $\beta$ cell function as a part of natural course of type 2 diabetes mellitus [1]-[3]. However, beta cell function rose promptly from $50 \%$ at diagnosis to $80 \%$ following treatment with sulfonylureas indicating induction of reversal in early duration in the course of the disease [4]. Several early studies have also demonstrated that sulfonylurea drugs improve insulin secretion and thus beta cell function in subjects with type 2 diabetes in the initial stage of the disorder [5] [6]. And more recently, other newer secretogogues; e.g., DPP4 Inhibitors and GLP1 analogs are also well documented to improve insulin secretion [7]-[13]. Thus, the decline in beta cell function noted at the time of diagnosis is apparently reversible. Moreover, several recent studies have documented apparent reversal of beta cell failure by reduction in the daily dose or even elimination of the requirement of insulin and/or oral antihyperglycemic drugs while attaining and maintaining desirable glycemic control following bariatric surgery in morbidly obese subjects with type 2 diabetes [14]-[16]. Similarly, reinitiation of oral agents and implementation of life style intervention including an appropriate diet and exercise with induction of weight loss also lowers the daily dose of insulin or eliminates the need for insulin in morbidly obese subjects with type 2 diabetes [17]-[22]. Therefore, these studies indicate that beta cell failure may not be irreversible even after prolonged duration of the disorder as emphasized in UKPDS but may actually be reversible. Finally, progressive beta cell failure suggested in UKPDS may be apparent rather than real because the gradual increase in the daily dosage of oral agents and insulin or need for use of multiple drug combinations required to maintain desirable glycemic control with increasing duration of diabetes may be actually secondary to rising insulin resistance due to weight gain [2] [3]. A similar observation was also noted in another "Adopt" clinical trial [23]. Finally, maintenance of desirable glycemic control (HbA1c $\leq 7 \%$ ) at 9 years in $25 \%$ of patients treated with SUs, $13 \%$ in metformin group and $11 \%$ managed with conventional program with life style intervention alone suggest that progressive beta cell failure may not be universal [24]. Therefore, progressive $\beta$ cell failure is neither universal, nor total, nor permanent and actually may be reversible. However, the exact mechanism of progressive $\beta$ cell failure remains to be defined. It is plausible that $\beta$ cell failure may be secondary to microangiopathy of the islets resulting in reduction in the number of $\beta$ cells as well as deranged function of the remnant since no organ or tissue is exempt from this complication. Moreover, in UKPDS, $\beta$ cell failure as reflected by rising HBA1c $>7.0$ on oral agents occurred around the same time as the time of onset of microvascular complications [1] [2]. Therefore, we examined epidemiologic correlation between presence of $\beta$ cell failure and well established microvascular complications.

\section{Subjects and Methods}

A retrospective study was conducted with a review of records of 650 subjects, 400 men and 250 women with a diagnosis of type 2 diabetes attending a diabetes clinic at Veterans Affairs Medical Center, Phoenix, Arizona between January and June 1996 as well as at Endocrinology clinic at University of Iowa Hospitals and Clinics, Iowa City, Iowa between October 1998 and June 1999. The study protocol was approved by research and development committees as well as institutional review boards at both institutions. We recorded the age, the duration of type 2 diabetes, HbA1c levels, treatment regimen consisting of life style modification consisting of diet and exercise or/and oral hypoglycemic agents (OHA) or/and insulin, as well as the presence of diabetes related microvascular complications: Neuropathy Retinopathy and Nephropathy. 
The subjects were divided into 4 groups according to the number of microvascular complications: 0 ) no complication; 1) one complication; 2) 2 complications and 3) 3 complications. Furthermore, the subjects were also divided into 2 further sub groups according to their $\beta$ cell function: 1) $\beta$ cell failure ( $\beta$-ve) defined as HbA1c > $7.0 \%$ with any therapy or HbA1c $\leq 7.0 \%$ with insulin, either monotherapy or in combination with oral agents and 2) $\beta$ cell function "preserved" $(\beta+$ ve) with $\mathrm{HbA1c} \leq 7.0 \%$ while receiving treatment consisting of lifestyle intervention including diet and exercise or/and oral drugs. Statistical methods used were continuous data analysis by parametric procedures including Student's t-test, ANOVA and as assessment of relative risks. Frequency distributions were analyzed by Chi Square procedures. Univariate and multivariate analyses were conducted for determining relative risks between two and multiple variable factors respectively. Statistical significance was defined as $\mathrm{p}<0.05$.

\section{Results}

The mean age of the subjects was $61 \pm 12$ years with the subjects with beta cell failure being significantly ( $<<$ 0.01 ) older, $70 \pm 8$ years in comparison to subjects with preserved beta cell function, $52 \pm 5$ years. However, no significant correlation was observed between age and beta cell failure The average duration of type 2 diabetes for the entire cohort was $12.2 \pm 8.7$ years (range 5 - 45 years).However, the average duration of diabetes was significantly longer $(\mathrm{p}<0.001)$ in patients with beta-cell failure when compared with subjects in whom beta cell function was preserved (Figure 1). Moreover, although no significant correlation was evident between the duration of diabetes on one aspect and number of subjects with beta cell failure on the other, beyond the duration of nine years, number of subjects with beta cell failure were significantly higher than the number of subjects with preserved beta cell function (Table 1). Finally, a distinct relationship was evident between the integrity of beta cell function and presence of microvascular complications (Table 2). The majority of subjects with no known microvascular complications manifested preserved beta cell function and the number of these subjects declined with increasing number of microvascular complications (Table 2). On the other hand, the number of subjects with beta cell failure progressively rose with increasing number of microvascular complications from 0 to 2 with no further significant rise with 3 complications (Table 2). Furthermore, the number of subjects with beta cell failure were significantly greater than number of subjects with preserved beat cell function even in presence of a single microcrovascular complication (Table 3). Finally, the relative risks progressively rose for the ratio, $\beta$ cell failure $/ \beta$ cell preserved with increasing number of microvascular complications as well as the duration of diabetes (Table 2). However, the relative risks remained significantly higher for $\beta$ cell failure with increasing number of complications even after eliminating the influence of age of the subjects and the duration of diabetes; $\mathrm{RR} \pm \mathrm{CI}$ vs 0 complication; $2.1 \pm 0.2$ for 1 complication; $3.1 \pm 0.4$ for 2 complications; $3.0 \pm 0.3$ for 3 complications $(\mathrm{p}<0.01$ for all correlations).

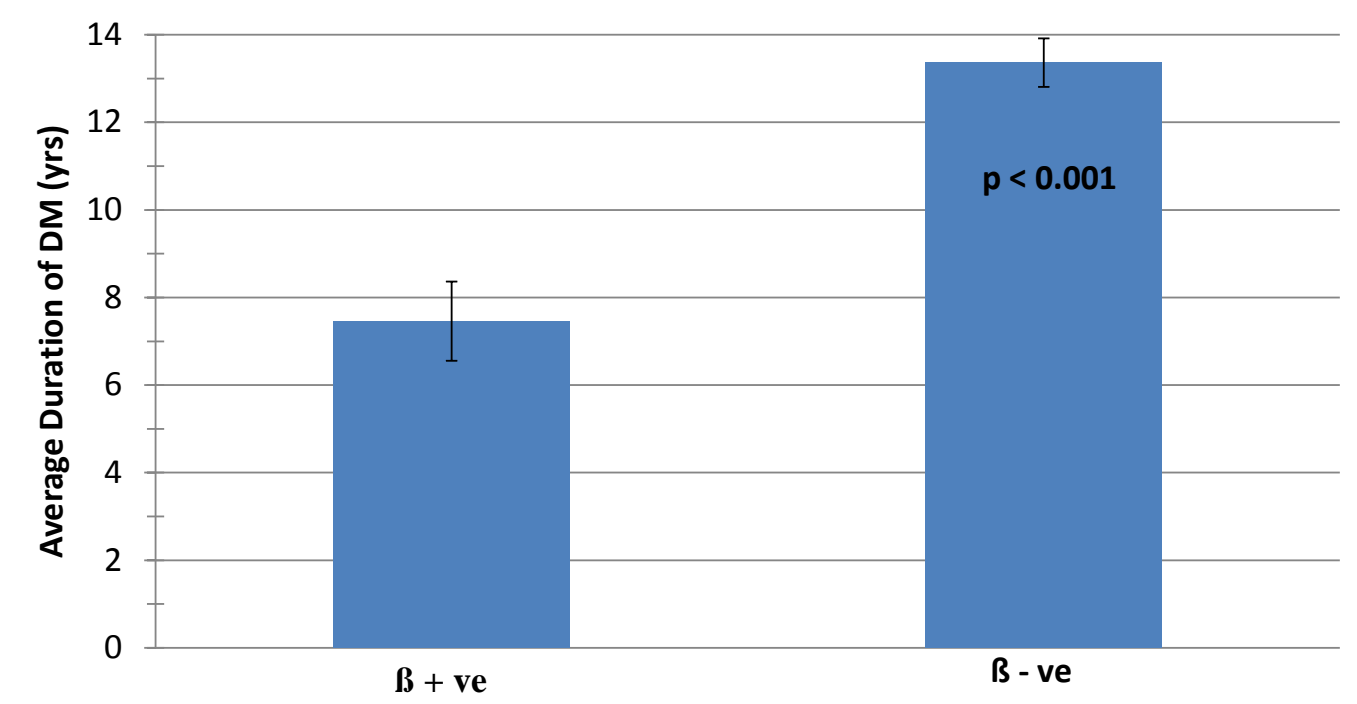

Figure 1. Duration of diabetes in subjects with preserved beta cell function $(\beta+$ ve) and with Beta cell Failure $(\beta-$ ve). 
Table 1. Number of subjects (\%) with preserved beta cell function $(\beta+$ ve) and beta cell failure $(\beta-\mathrm{ve})$ as well as proportion of $\beta-$ ve/ $\beta+$ ve in groups divided according the duration (years) of type 2 Diabetes.

\begin{tabular}{ccccc}
\hline Beta cell function & $0-9$ & $10-19$ & $20-29$ & $>29$ \\
\hline$\beta+\mathrm{ve}$ & 72 & 18 & 6 & 6.0 \\
$\beta-\mathrm{ve}$ & 40 & 32 & 22 & $3.0^{\dagger}$ \\
$\beta-\mathrm{ve} / \beta+\mathrm{ve}$ & 0.55 & $1.8^{*}$ & $3.6^{\dagger}$ & $5.7 \pm 0.68^{\dagger}$ \\
$\mathrm{RR} \pm \mathrm{CI}^{\ddagger}$ & & $3.3 \pm 0.39^{\dagger}$ & $6.5 \pm 0.84^{\dagger}$ & 5.0 \\
\hline
\end{tabular}

${ }^{*} \mathrm{p}<0.01$ vs. group $0 ;{ }^{\dagger} \mathrm{p}<0.001$ vs. group $0 ;{ }^{\ddagger} \mathrm{RR}$ (relative risk) $\pm \mathrm{CI}$ (confidence interval) for $\beta-$ ve/ $\beta+$ ve.

Table 2. Number of subjects with preserved beta cell function $(\beta+$ ve) and beta cell failure $(\beta-$ ve) as well as proportion of $\beta-\mathrm{ve} / \beta+$ ve in groups divided according to number of microvascular complications (MC). \% of patients are shown in parentheses.

\begin{tabular}{ccccc}
\hline No. of MC & 0 & 1 & 2 & 3 \\
\hline$\beta+$ ve & $193(65)$ & $67(34)^{*}$ & $12(13)^{\dagger}$ & $9(14)^{\dagger}$ \\
$\beta$ - ve & $105(35)$ & $127(66)^{*}$ & $83(87)^{\dagger}$ & $54(86)^{\dagger}$ \\
Total & $298(100)$ & $194(100)$ & $95(100)$ & $63(100)$ \\
$\beta$ - vel $\beta+$ ve & 0.65 & $1.9^{*}$ & 6.7 & 6.2 \\
RR $\pm \mathrm{CI}^{\ddagger}$ & & $3.0 \pm 0.22^{*}$ & $10.3 \pm 0.77^{\dagger}$ & $9.5 \pm 0.65^{\dagger}$ \\
\hline
\end{tabular}

${ }^{*} \mathrm{p}<0.01$ vs. group $0 ;{ }^{\dagger} \mathrm{p}<0.001$ vs. group $0 ;{ }^{\ddagger} \mathrm{RR}$ (relative risk) $\pm \mathrm{CI}$ (confidence interval) for $\beta-$ ve $/ \beta+$ ve.

Table 3. Prevalence of individual microvascular complication (neuropathy, retinopathy, nephropathy) in subjects with type 2 diabetes divided according to beta cell function*.

\begin{tabular}{cccc}
\hline Beta cell function & Neuropathy & retinopathy & Nephropathy \\
\hline Beta cell preserved & $23 \%$ & $12 \%$ & $15 \%$ \\
Beta cell failure & $49 \%^{\dagger}$ & $33 \%{ }^{\dagger}$ & $27 \%^{\dagger}$ \\
\hline
\end{tabular}

${ }^{*}$ Some patients manifested more than one microvascular complication. (Table 1$)^{\dagger} \mathrm{p}<0.01$.

\section{Discussion}

Progressive beta cell failure has been proposed to be the natural course of the disorder of type 2 diabetes [1]-[3]. However, the pathophysiologic mechanism of the progressive beta cell failure remains to be elucidated. A recent publication focused on several hypotheses regarding possible mechanisms and recommended a direction for future research [25]. Another recent study proposed oxidative stress to play a major role in induction of decline of beta cell mass via several mechanisms [26]. The average duration of diabetes in this study [26] in subjects with beta cell failure of almost 10 years is similar to the duration of diabetes over 9 years in the majority of subjects with beta cell failure in our study which demonstrated that beta cell failure may be related to the duration of diabetes as well. However, the prevalence of microvascular complications in this study [26] is not documented. We believe that the relationship between aging and duration of diabetes on one hand and beta cell failure on the other is similar to relationships between these 2 factors on one aspect and onset and progression of microvascular complications on the other [27]-[29]. Moreover, the progressive rise in number of subjects with beta cell failure and a gradual decline in number of subjects with preserved beta cell function with increasing number of microvascular complications noted in this study may indicate a distinct epidemiological relationship between beta cell failure and microvascular complications. Therefore, it is plausible that progressive beta cell failure may also be a microvascular complication involving beta cells themselves or pancreatic islets. We believe that onset and progression of beta cell failure may be secondary to by fibrosis of beta cells or pancreatic islets caused by a disruption of blood supply due to occlusion or narrowing of microvasculture of the islets as documented in an autopsy study [30]. The same mechanism may be responsible for oxidative stress in islets described in another 
study [26].

Pathogenesis of microvascular complications in diabetes is attributed to deposition of advanced glycated products [31]-[33]. Deposition of Amylin, an Amyloid, a glycoprotein in pancreatic islets documented in type 2 DM [34] [35] may be similar to deposition of advanced glycated products causing microvascular involvement in other tissues and therefore may also be a causative factor in inducing fibrosis of pancreatic islets (isletopathy) with consequential reduction in beta cell mass and therefore insulin secretion.

Prevention or delay in onset of micrvascular complications by attaining and maintaining desirable glycemic control in both type 1 and type 2 diabetes is well established [36]-[42]. Therefore, achieving and preserving desirable glycemic control may also prevent and delay occurrence of beta cell failure "microvascular pancreatic isletopathy" as documented recently in subjects with type 2 diabetes treated with oral agents or insulin glargine over a 6 year period [36]-[42]. This hypothesis is also consistent with the documentation of a significantly longer period of preserved beta cell function (Honey moon Period) in subjects with type 1 diabetes in DCCT [43]. Moreover, persistent preserved beta cell function in many subjects with type 2 diabetes for upto 9 years noted in UKPDS adds credence to our hypothesis of "pancreatic isletopathy" [24]. Finally, a documentation of islet cell fibrosis in post mortem examination in subjects with type 2 diabetes [30] may be a further evidence of "macrovascular pancreatic isletopathy".

Therefore we propose that the onset and progression of beta cell failure in type 2 DM may be attributed to microvascular disease of the Pancreatic Islets (Isletopathy), similar to other microvascular complications and therefore may be influenced by glycemic control.

\section{References}

[1] Leahy, J.L. (1990) Natural History of Beta-Cell Dysfunction in NIDDM. Diabetes Care, 3, 992-1010. http://dx.doi.org/10.2337/diacare.13.9.992

[2] UK Prospective Diabetes Study (UKPDS) Group (1998) Intensive Blood-Glucose Control with Sulphonylureas or Insulin Compared with Conventional Treatment and Risk of Complications in Patients with Type 2 Diabetes (UKPDS 33). Lancet, 352, 837-853. http://dx.doi.org/10.1016/S0140-6736(98)07019-6

[3] UK Prospective Diabetes Study (UKPDS) Group (1998) Effect of Intensive Blood-Glucose Control with Metformin on Complications in Overweight Patients with Type 2 Diabetes (UKPDS 34). Lancet, 352, 854-65. http://dx.doi.org/10.1016/S0140-6736(98)07037-8

[4] UK Prospective Diabetes Study Group (1995) U.K. Prospective Diabetes Study 16. Overview of 6 Years' Therapy of Type II Diabetes: A Progressive Disease. Diabetes, 44, 1249-1258. http://dx.doi.org/10.2337/diab.44.11.1249

[5] Ahrén, B., Lundquist, I. and Scherstén, B. (1986) Effects of Glipizide on Various Consecutive Insulin Secretory Stimulations in Patients with Type 2 Diabetes. Diabetes Research, 3, 293-300.

[6] Kabadi, M.U. and Kabadi, U.M. (2004) Effects of Glimepiride on Insulin Secretion and Sensitivity in Patients with Recently Diagnosed Type 2 Diabetes Mellitus. Clinical Therapeutics, 26, 63-69.

[7] Shah, P., Ardestani, A., Dharmadhikari, G., Laue, S., Schumann, D.M., Kerr-Conte, J., Pattou, F., Klein, T. and Maedler, K. (2013) The DPP-4 Inhibitor Linagliptin Restores $\beta$-Cell Function and Survival in Human Isolated Islets through GLP-1 Stabilization. Journal of Clinical Endocrinology \& Metabolism, 98, E1163-E1172.

[8] Sjöstrand, M., Iqbal, N., Lu, J. and Hirshberg, B. (2014) Saxagliptin Improves Glycemic Control by Modulating Postprandial Glucagon and C-Peptide Levels in Chinese Patients with Type 2 Diabetes. Diabetes Research and Clinical Practice, 105, 185-191. http://dx.doi.org/10.1016/j.diabres.2014.05.006

[9] Kozawa, J., Kitamura, T., Nishizawa, H., Yasuda, T., Maeda, N., Otsuki, M., Okita, K., Iwahashi, H., Kaneto, H., Funahashi, T., Imagawa, A. and Shimomura, I. (2013) Dipeptidyl Peptidase-4 Inhibitors Are Effective in Japanese Type 2 Diabetic Patients with Sustained Endogenous Insulin-Secreting Capacity, a Higher Body Mass Index and Insulin Resistance. Journal of Diabetes Investigation, 4, 190-194. http://dx.doi.org/10.1111/jdi.12016

[10] Vilsbøll, T. (2009) The Effects of Glucagon-Like Peptide-1 on the Beta Cell. Diabetes, Obesity and Metabolism, 11, 11-18.

[11] Mudaliar, S. and Henry, R.R. (2010) Effects of Incretin Hormones on Beta-Cell Mass and Function, Body Weight, and Hepatic and Myocardial Function. The American Journal of Medicine, 123, S19-S27. http://dx.doi.org/10.1016/j.amjmed.2009.12.006

[12] Takabe, M., Matsuda, T., Hirota, Y., Hashimoto, N., Nakamura, T., Sakaguchi, K., Ogawa, W. and Seino, S. (2012) C-Peptide Response to Glucagon Challenge Is Correlated with Improvement of Early Insulin Secretion by Liraglutide Treatment. Diabetes Research and Clinical Practice, 98, e32-e35. http://dx.doi.org/10.1016/j.diabres.2012.09.036 
[13] Hartman, I., Rojas, E. and Rodríguez-Molina, D. (2013) Incretin-Based Therapy for Type 2 Diabetes Mellitus: Pancreatic and Extrapancreatic Effects. American Journal of Therapeutics, 20, 384-393. http://dx.doi.org/10.1097/MJT.0b013e318235f27d

[14] Kashyap, S.R., Bhatt, D.L., Wolski, K., Watanabe, R.M., Abdul-Ghani, M., Abood, B., Pothier, C.E., Brethauer, S., Nissen, S., Gupta, M., Kirwan, J.P. and Schauer, P.R. (2013) Metabolic Effects of Bariatric Surgery in Patients with Moderate Obesity and Type 2 Diabetes: Analysis of a Randomized Control Trial Comparing Surgery with Intensive Medical Treatment. Diabetes Care, 36, 2175-2182. http://dx.doi.org/10.2337/dc12-1596

[15] Guo, X., Liu, X., Wang, M., Wei, F., Zhang, Y. and Zhang, Y. (2013) The Effects of Bariatric Procedures versus Medical Therapy for Obese Patients with Type 2 Diabetes: Meta-Analysis of Randomized Controlled Trials. BioMed Research International, 2013, 1-11. http://dx.doi.org/10.1155/2013/410609

[16] Schauer, P.R., Bhatt, D.L., Kirwan, J.P., Wolski, K., Brethauer, S.A., Navaneethan, S.D., Aminian, A., Pothier, C.E., Kim, E.S., Nissen, S.E. and Kashyap, S.R., STAMPEDE Investigators (2014) Bariatric Surgery versus Intensive Medical Therapy for Diabetes-3-Year Outcomes. The New England Journal of Medicine, 370, 2002-2013. http://dx.doi.org/10.1056/NEJMoa1401329

[17] Del Prato, S., Vigili de Kreutzenberg, S., Riccio, A., Maifreni, L., Duner, E., Lisato, G., Iavicoli, M. and Tiengo, A. (1990) Partial Recovery of Insulin Secretion and Action after Combined Insulin-Sulfonylurea Treatment in Type 2 (Non-Insulin-Dependent) Diabetic Patients with Secondary Failure to Oral Agents. Diabetologia, 33, 688-695. http://dx.doi.org/10.1007/BF00400571

[18] Johnson, J.L., Wolf, S.L. and Kabadi, U.M. (1996) Efficacy of Insulin and Sulfonylurea Combination Therapy in Type II Diabetes. A Meta-Analysis of the Randomized Placebo-Controlled Trials. Archives of Internal Medicine, 156, 259264. http://dx.doi.org/10.1001/archinte.1996.00440030049007

[19] Kabadi, M.U. and Kabadi, U.M. (2003) Efficacy of Sulfonylureas with Insulin in Type 2 Diabetes Mellitus. Annals of Pharmacotherapy, 37, 1572-1576. http://dx.doi.org/10.1345/aph.1C492

[20] Kabadi, U.M. and Kabadi, M. (2006) Comparative Efficacy of Glimepiride and/or Metformin with Insulin in Type 2 Diabetes. Diabetes Research and Clinical Practice, 72, 265-270. http://dx.doi.org/10.1016/j.diabres.2005.10.024

[21] Yu, J.G., Kruszynska, Y.T., Mulford, M.I. and Olefsky, J.M. (1999) A Comparison of Troglitazone and Metformin on Insulin Requirements in Euglycemic Intensively Insulin-Treated Type 2 Diabetic Patients. Diabetes, 48, 2414-2421. http://dx.doi.org/10.2337/diabetes.48.12.2414

[22] Jain, R., Kabadi, U. and Kabadi, M. (2008) Is Beta-Cell Failure in Type 2 Diabetes Mellitus Reversible? International Journal of Diabetes in Developing Countries, 28, 1-5. http://dx.doi.org/10.4103/0973-3930.41978

[23] Reaven, G.M. (2009) HOMA-Beta in the UKPDS and ADOPT. Is the Natural History of Type 2 Diabetes Characterised by a Progressive and Inexorable Loss of Insulin Secretory Function? Maybe? Maybe Not? Diabetes and Vascular Disease Research, 6, 133-138. http://dx.doi.org/10.1177/1479164109336038

[24] Turner, R.C., Cull, C.A., Frighi, V. and Holman, R.R. (1999) Glycemic Control with Diet, Sulfonylurea, Metformin, or Insulin in Patients with Type 2 Diabetes Mellitus: Progressive Requirement for Multiple Therapies (UKPDS 49). Journal of the American Medical Association, 281, 2005-2012. http://dx.doi.org/10.1001/jama.281.21.2005

[25] Halban, P.A., Polonsky, K.S., Bowden, D.W., Hawkins, M.A., Ling, C., Mather, K.J., et al. (2014) $\beta$-Cell Failure in Type 2 Diabetes: Postulated Mechanisms and Prospects for Prevention and Treatment. Journal of Clinical Endocrinology \& Metabolism, 99, 1983-1992. http://dx.doi.org/10.1210/jc.2014-1425

[26] Mizukami, H., Takahashi, K., Inaba, W., Tsuboi, K., Osonoi, S., Yoshida, T. and Yagihashi, S. (2014) Involvement of Oxidative Stress-Induced DNA Damage, Endoplasmic Reticulum Stress and Autophagy Deficits in the Decline of $\beta$-Cell Mass in Japanese Type 2 Diabetic Patients. Diabetes Care, 37, 1966-1974. http://dx.doi.org/10.2337/dc13-2018

[27] Thai Multicenter Research Group on Diabetes Mellitus (1994) Vascular Complications in Non-Insulin Dependent Diabetics in Thailand. Diabetes Research and Clinical Practice, 25, 61-69.

[28] Kumar, H.K., Kota, S., Basile, A. and Modi, K. (2012) Profile of Microvascular Disease in Type 2 Diabetes in a Tertiary Health Care Hospital in India. Annals of Medical and Health Sciences Research, 2, 103-108. http://dx.doi.org/10.4103/2141-9248.105654

[29] Huang, E.S., Laiteerapong, N., Liu, J.Y., John, P.M., Moffet, H.H. and Karter, A.J. (2014) Rates of Complications and Mortality in Older Patients with Diabetes Mellitus: The Diabetes and Aging Study. JAMA Internal Medicine, 174, 251258. http://dx.doi.org/10.1001/jamainternmed.2013.12956

[30] Hayden, M.R. (2007) Islet Amyloid and Fibrosis in the Cardiometabolic Syndrome and Type 2 Diabetes Mellitus. Journal of the Cardio Metabolic Syndrome, 2, 70-75. http://dx.doi.org/10.1111/j.1559-4564.2007.06159.x

[31] Friedman, E.A. (1999) Advanced Glycosylated End Products and Hyperglycemia in the Pathogenesis of Diabetic Complications. Diabetes Care, 2, B65-B71.

[32] Goh, S.Y. and Cooper, M.E. (2008) Clinical Review: The Role of Advanced Glycation End Products in Progression 
and Complications of Diabetes. Journal of Clinical Endocrinology \& Metabolism, 93, 1143-1152. http://dx.doi.org/10.1210/jc.2007-1817

[33] Kostolanská, J., Jakus, V. and Barák, L. (2009) Monitoring of Early and Advanced Glycation in Relation to the Occurrence of Microvascular Complications in Children and Adolescents with Type 1 Diabetes Mellitus. Physiological Research, 58, 553-561.

[34] Johnson, K.H., O’Brien, T.D., Betsholtz, C. and Westermark, P. (1989) Islet Amyloid, Islet-Amyloid Polypeptide, and Diabetes Mellitus. New England Journal of Medicine, 321, 513-518. http://dx.doi.org/10.1056/NEJM198908243210806

[35] Hull, R.L., Westermark, G.T., Westermark, P. and Kahn, S.E. (2004) Islet Amyloid: A Critical Entity in the Pathogenesis of Type 2 Diabetes. The Journal of Clinical Endocrinology \& Metabolism, 89, 3629-3643. http://dx.doi.org/10.1210/jc.2004-0405

[36] DCCT Research Group (1993) Intensive Diabetes Treatment and Complications in IDDM. New England Journal of Medicine, 329, 977-986.

[37] Del Prato, S., Bianchi, C. and Marchetti, P. (2007) Beta-Cell Function and Anti-Diabetic Pharmacotherapy. Diabetes/ Metabolism Research and Reviews, 23, 518-527. http://dx.doi.org/10.1002/dmrr.770

[38] Lim, E.L., Hollingsworth, K.G., Aribisala, B.S., Chen, M.J., Mathers, J.C. and Taylor, R. (2011) Reversal of Type 2 Diabetes: Normalisation of Beta Cell Function in Association with Decreased Pancreas and Liver Triacylglycerol. Diabetologia, 54, 2506-2514. http://dx.doi.org/10.1007/s00125-011-2204-7

[39] Hermans, M.P., Ahn, S.A. and Rousseau, M.F. (2012) The Atherogenic Dyslipidemia Ratio [Log(TG)/HDL-C] Is Associated with Residual Vascular Risk, Beta-Cell Function Loss and Microangiopathy in Type 2 Diabetes Females. Lipids in Health and Disease, 11, 132. http://dx.doi.org/10.1186/1476-511X-11-132

[40] Eliaschewitz, F.G. and Tambascia, M.A. (2012) Can We Prevent Beta Cell Apoptosis in Type 2 Diabetes? Diabetes/ Metabolism Research and Reviews. http://dx.doi.org/10.1002/dmrr.2381

[41] Origin Trial Investigators (2012) Basal Insulin and Cardiovascular and Other Outcomes in Dysglycemia. New England Journal of Medicine, 367, 319-328. http://dx.doi.org/10.1056/NEJMoa1203858

[42] ORIGIN Trial Investigators, Gilbert, R.E., Mann, J.F., Hanefeld, M., Spinas, G., Bosch, J., Yusuf, S. and Gerstein, H.C. (2014) Basal Insulin Glargine and Microvascular Outcomes in Dysglycaemic Individuals: Results of the Outcome Reduction with an Initial Glargine Intervention (ORIGIN) Trial. Diabetologia, 57, 1325-1331. http://dx.doi.org/10.1007/s00125-014-3238-4

[43] DCCT Research Group (1998) Effect of Intensive Therapy on Residual Beta Cell Function in Patients with Type 1 Diabetes in the Diabetes Control and Complications Trial. A Randomized Control Trial. Annals of Internal Medicine, 128, 517-523. http://dx.doi.org/10.7326/0003-4819-128-7-199804010-00001 
Scientific Research Publishing (SCIRP) is one of the largest Open Access journal publishers. It is currently publishing more than 200 open access, online, peer-reviewed journals covering a wide range of academic disciplines. SCIRP serves the worldwide academic communities and contributes to the progress and application of science with its publication.

Other selected journals from SCIRP are listed as below. Submit your manuscript to us via either submit@scirp.org or Online Submission Portal.
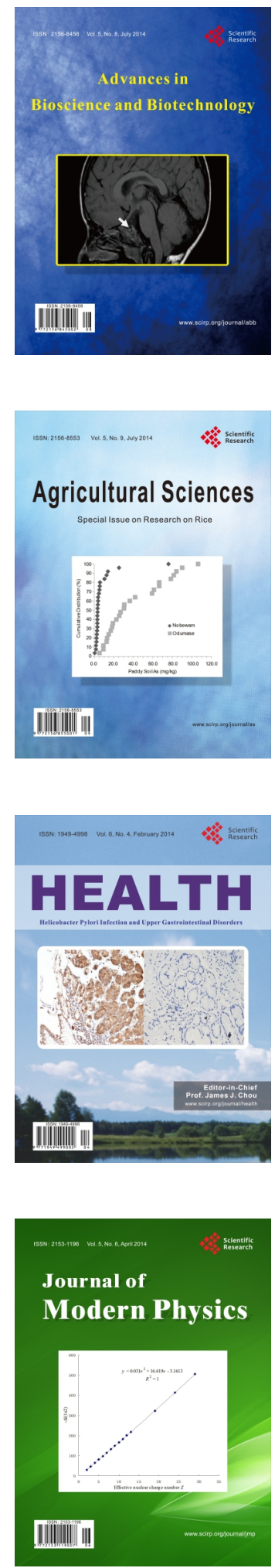
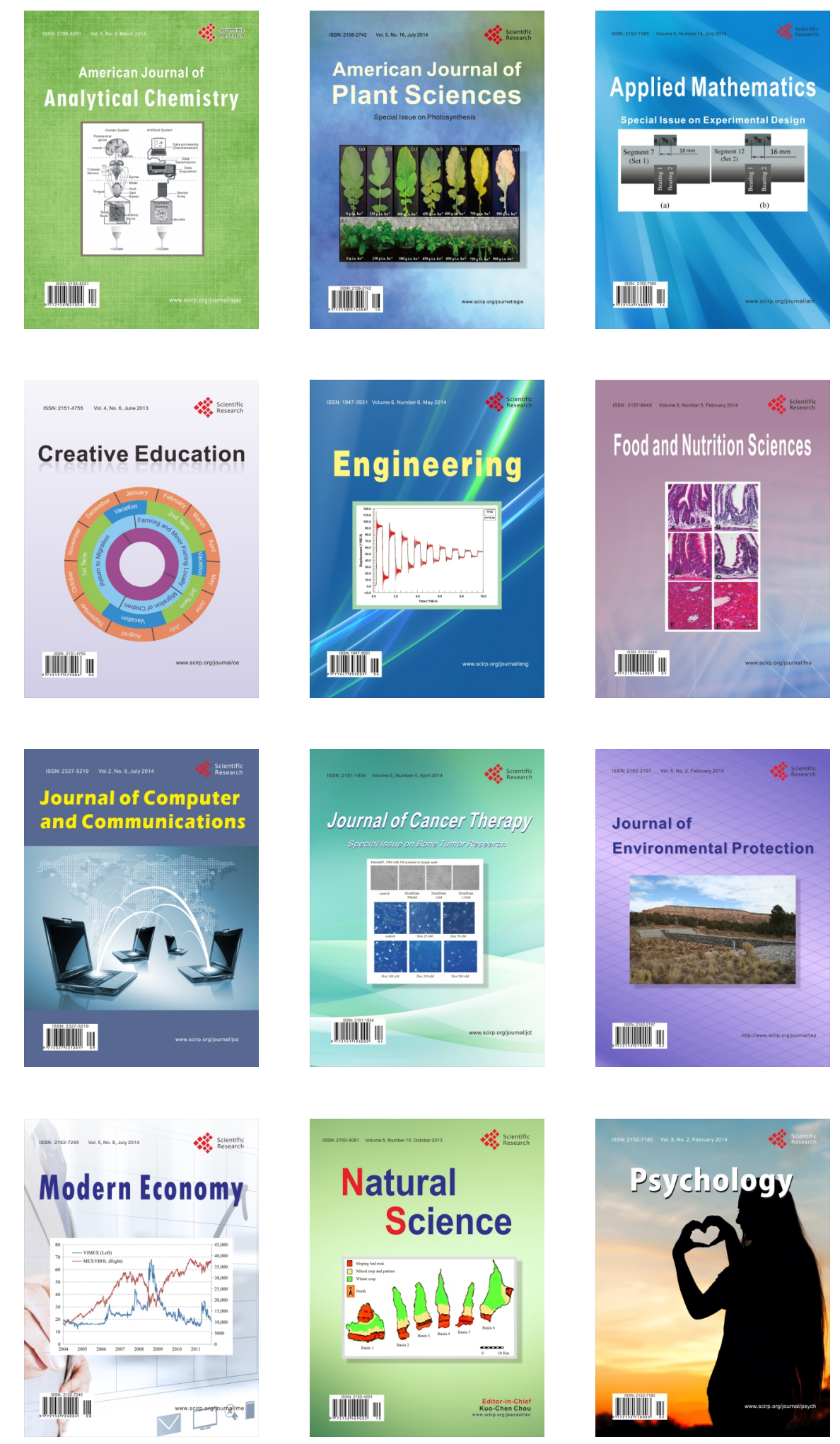